Running title: Psychological distress

\title{
Prevalence and associated factors of psychological distress among a national sample of in-school adolescents in Bhutan
}

Supa Pengpid ${ }^{1,2}$ and Karl Peltzer ${ }^{3}$

\author{
${ }^{1}$ ASEAN Institute for Health Development, Mahidol University, Salaya, Phutthamonthon, \\ Nakhon Pathom, Thailand \\ ${ }^{2}$ Department of Research Administration and Development, University of Limpopo, \\ Turfloop, South Africa \\ ${ }^{3}$ Department of Psychology, University of the Free State, Bloemfontein, South Africa
}

Corresponding author at: Karl Peltzer, University of the Free State, Bloemfontein, South Africa; Email: kfpeltzer@gmail.com

\begin{abstract}
The goal of the study was to estimate the prevalence and correlates of psychological distress (=PD) among adolescent school children in Bhutan. Nationally representative cross-sectional data were analysed from 7,576 adolescents (16 years median age) that took part in the "2016 Bhutan Global School-Based Student Health Survey (GSHS).” PD was assessed with a 2item screening measure (BMC Psychiatry. DOI: 10.1186/s12888-020-02888-3). Results indicate that the prevalence of PD was $15.8 \%, 12.8 \%$ among males and $18.4 \%$ among females. In the adjusted logistic regression analysis, female sex, having no close friends, older age, bullying victimization, infrequently physically attacked, parental emotional neglect, parents never check home work, passive smoking trouble from alcohol use, ever
\end{abstract}


having sex, high sedentary behaviour and having sustained single or multiple serious injuries (past year) were associated with PD. In addition, adequate fruit and vegetable consumption are protective against PD. Almost one in six students reported PD and several associated factors were identified which can aid prevention and control strategies.

Key words: Risk behaviour, social factors, psychological distress, adolescents, Bhutan

\section{Introduction}

Among adolescents, "mental health conditions account for $16 \%$ of the global burden of disease and injury" [1], and the "worldwide pooled prevalence of mental disorders was 13.4\%" [2]. "First onset of mental disorders usually occurs in childhood or adolescence" [3]. "Adolescence is a critical period characterised by vulnerability to psychological distress (=PD), and is therefore an important time for the promotion of psychological well-being and early mental health intervention, in order to safeguard against the development of mental health issues" [4] (p. 1011). According to the American Psychological Association [5], PD is "a set of painful mental and physical symptoms that are associated with normal fluctuations of mood in most people. It is thought to be what is assessed by many putative self-report measures of depression and anxiety."

The prevalence of moderate to severe PD (measured with the Kessler K-10) was $10.5 \%$ among school-going adolescents in India [6], and among adolescents in four Asian countries, PD was $32.9 \%$ (presence of any item: suicidal ideation, plans and suicide attempts, loneliness, sadness and anxiety) [7]. In a study among adolescents in Afghanistan, the prevalence of PD was $27.7 \%$ ( $\geq 2$ items of no close friends, loneliness, anxiety, suicidal ideation, and suicide attempt) [8], and among adolescents in Iran, 17.7\% ( $\geq 3$ items of worthless, anxious, angriness, confusion, and insomnia) had PD [9]. In a national survey among persons 15 years and older in Bhutan, the prevalence of PD (measured with the GHQ12) was $29.3 \%, 26.9 \%$ among $15-24$ year olds [10]. In a small study among secondary school students $(\mathrm{N}=131)$ in Mongar district, Eastern Nepal, the total mean mental health score (measured with the Mental Health Inventory) was 52.7 (range 0-100, with higher scored showing better mental health) [11]. There is a lack of national data on the prevalence and correlates of PD among adolescents in Bhutan. To prevent and control PD in adolescent populations, it is vital to assess its prevalence and risk factors [12]. 
Factors associated with PD among adolescents can be divided into social distresses, socio-environmental factors, and health risk behaviours [13], and may include, as reviewed previously [14], sociodemographic factors (older age, female sex), social distresses (interpersonal violence), socio-environmental factors (experience of hunger, low peer and low parental support and school truancy) and health risk behaviours (sedentary behaviour, substance use, sexual behaviour and injury). This investigation aimed at estimating the prevalence and correlates of PD among adolescents in Bhutan.

\section{Methods}

\section{Sources of data}

Nationally representative data from the cross-sectional "2016 Bhutan GSHS" were analyzed [15]; the study response rate was 95\%; more details [15]. "The Research Ethics Board of Health in Bhutan approved the study and written informed consent was obtained from the participating schools, parents, and students.” [15].

\section{Measures}

The administered questionnaire items used are shown in Table 1 [15]. PD was assessed with one item on anxiety, "During the past 12 months, how often have you been so worried about something that you could not sleep at night?" and one item on depression, "During the past 12 months, how often have you felt lonely?" Response options included and were coded as "Never $=0$, Rarely $=1$, Sometimes $=1$, Most of the time=2, Always $=3 "$ Scores of the two items were summed and scores three or more were defined as PD, in line with previous research [16]. Emotional neglect was defined as never "parental or guardian understanding of your problems and worries? AND never parents or guardians really know what you were doing with your free time when you were not at school or work?" [17].

Table 1: Description of variables

\begin{tabular}{|c|c|c|}
\hline Variables & Items & Responses (coding) \\
\hline Anxiety & $\begin{array}{c}\text { "During the past } 12 \text { months, how often have you been so worried about } \\
\text { something that you could not sleep at night?" }\end{array}$ & "1=never to $5=$ always" \\
\hline Loneliness & "During the past 12 months, how often have you felt lonely?" & " $1=$ never to $5=$ always" \\
\hline Age & "How old are you?" & $\begin{array}{c}\text { "11 years old or younger to } 18 \text { years old } \\
\text { or older" }\end{array}$ \\
\hline Sex & "What is your sex?" & "Male, Female" \\
\hline No close friends & $\begin{array}{c}\text { Social distress } \\
\text { "How many close friends do you have?" }\end{array}$ & $\begin{array}{c}" 1=0 \text { to } 4=3 \text { or more }(\operatorname{coded} 1+=0, \\
0=1) "\end{array}$ \\
\hline Bullied & "During the past 30 days, on how many days were you bullied?" & " $1=0$ days to $7=$ All 30 days" \\
\hline
\end{tabular}




\begin{tabular}{|c|c|c|}
\hline Physically attacked & $\begin{array}{c}\text { "During the past } 12 \text { months, how many times were you physically } \\
\text { attacked?" }\end{array}$ & $" 1=0$ times to $8=12$ or more times" \\
\hline Physical fights & $\begin{array}{l}\text { "During the past } 12 \text { months, how many times were you in a physical } \\
\text { fight?" }\end{array}$ & $" 1=0$ times to $8=12$ or more times" \\
\hline Peer support & $\begin{array}{l}\text { Social-environmental factos } \\
\text { "During the past } 30 \text { days, how often were most of the students in your } \\
\text { school kind and helpful?" }\end{array}$ & $\begin{array}{l}\text { " } 1=\text { never to } 5=\text { always }(\operatorname{coded} 1-2=1,3- \\
5=0) "\end{array}$ \\
\hline Parental supervision & $\begin{array}{l}\text { "During the past } 30 \text { days, how often did your parents or guardians check } \\
\text { to see if your homework was done?" }\end{array}$ & $\begin{array}{c}" 1=\text { never to } 5=\text { always }(\operatorname{coded} 1=1 \text { and } \\
2-5=0) "\end{array}$ \\
\hline \multirow[t]{2}{*}{$\begin{array}{l}\text { Parental emotional } \\
\text { neglect }\end{array}$} & $\begin{array}{l}\text { "During the past } 30 \text { days, how often did your parents or guardians } \\
\text { understand your problems and worries?" }\end{array}$ & $\begin{array}{c}\text { " } 1=\text { never to } 5=\text { always }(\operatorname{coded} 1=1 \text { and } 2- \\
5=0) "\end{array}$ \\
\hline & $\begin{array}{l}\text { "During the past } 30 \text { days, how often did your parents or guardians really } \\
\text { know what you were doing with your free time?" }\end{array}$ & $\begin{array}{c}\text { " } 1=\text { never to } 5=\text { always }(\operatorname{coded} 1-2=1 \text { and } \\
3-5=0) "\end{array}$ \\
\hline $\begin{array}{l}\text { Parental disrespect } \\
\quad \text { for privacy }\end{array}$ & $\begin{array}{l}\text { "During the past } 30 \text { days, how often did your parents or guardians go } \\
\text { through your things without your approval?" }\end{array}$ & $\begin{array}{c}\text { " } 1=\text { never to } 5=\text { always }(\operatorname{coded} 1-3=0 \text { and } \\
4-5=1) "\end{array}$ \\
\hline Passive smoking & $\begin{array}{l}\text { "During the past } 7 \text { days, on how many days have people smoked in your } \\
\text { presence?" }\end{array}$ & $" 1=0$ days to $5=$ all 7 days" \\
\hline School truancy & $\begin{array}{c}\text { "During the past } 30 \text { days, on how many days did you miss classes or } \\
\text { school without permission?" }\end{array}$ & $" 1=0$ days to $5=10$ or more days" \\
\hline & $\begin{array}{l}\text { Health risk behaviours } \\
\text { "During the past } 30 \text { davs on how many days did you smoke }\end{array}$ & \\
\hline Current tobacco use & $\begin{array}{c}\text { cigarettes/use any tobacco products other than cigarettes, such as baba, } \\
\text { khaine, or raja?" }\end{array}$ & $\begin{array}{c}" 1=0 \text { days to } 7=\text { All } 30 \text { days }(\text { coded } 1=0 \\
\text { and } 2-7=1) "\end{array}$ \\
\hline Current cannabis use & $\begin{array}{c}\text { "During the past } 30 \text { days, how many times have you used marijuana } \\
\text { (also called ganja, black, kayna, or weed)?" }\end{array}$ & $\begin{array}{c}" 1=0 \text { times to } 5=20 \text { or more times } \\
\quad(\text { coded } 1=0 \text { and } 2-5=1) "\end{array}$ \\
\hline $\begin{array}{l}\text { Trouble from alcohol } \\
\text { use }\end{array}$ & $\begin{array}{c}\text { "During your life, how many times have you got into trouble with your } \\
\text { family or friends, missed school, or got into fights, as a result of drinking } \\
\text { alcohol?" }\end{array}$ & $\begin{array}{c}\text { " } 1=0 \text { times to } 4=10 \text { or more times } \\
\quad(\text { coded } 1=0 \text { and } 2-4=1) "\end{array}$ \\
\hline Ever sex & "Have you ever had sexual intercourse?" & "Yes, No" \\
\hline $\begin{array}{l}\text { Leisure-time } \\
\text { sedentary behavior }\end{array}$ & $\begin{array}{l}\text { "How much time do you spend during a typical or usual day sitting and } \\
\text { watching television, playing computer games, talking with friends, or } \\
\text { doing other sitting activities, such as listening to music?" }\end{array}$ & $\begin{array}{l}\text { " } 1=\text { Less than } 1 \text { hour per day .. } 3=3 \text { to } 4 \\
\text { hours per day } \ldots 6=8 \text { or more hours a day" }\end{array}$ \\
\hline Fruits & $\begin{array}{l}\text { "During the past } 30 \text { days, how many times per day did you usually eat } \\
\text { fruit such as apples or oranges?" }\end{array}$ & $\begin{array}{l}\text { " } 1=\mathrm{I} \text { did not eat fruit during the past } 30 \\
\text { days to } 7=5 \text { or more times per day" }\end{array}$ \\
\hline Vegetables & $\begin{array}{l}\text { "During the past } 30 \text { days, how many times per day did you usually eat } \\
\text { vegetables, such as cabbage, cauliflower, carrots, or broccoli?" }\end{array}$ & $\begin{array}{l}\text { "I did not eat vegetables during the past } \\
30 \text { days to } 7=5 \text { or more times per day" }\end{array}$ \\
\hline Injury & $\begin{array}{c}\text { "During the past } 12 \text { months, how many times were you seriously } \\
\text { injured?" }\end{array}$ & $\begin{array}{c}" 1=0 \text { times to } 8=12 \text { or more times } \\
\quad(\text { coded } 1=0 \text { and } 2-8=1) "\end{array}$ \\
\hline
\end{tabular}

\section{Data analysis}

Statistical analyses were done with "STATA software version 15.0 (Stata Corporation, College Station, Texas, USA).” Unadjusted and adjusted (with variables significant in unadjusted analysis) logistic regression analyses were used to assess predictors of PD. Only complete cases formed part of the analyses, and $p<0.05$ indicated significance.

\section{Results}

\section{Sample and psychological distress characteristics}

The participants comprised of 7,576 school adolescents (median, 16 years), 51.9\% were female, and $52.1 \%$ lived in rural areas. Almost one in ten of the participants $(9.1 \%)$ had no close friends, $8.5 \%$ had frequently been bullied, $24.2 \%$ had frequently been assaulted, and $21.0 \%$ had frequently been involved in physical fighting. Almost one in three students 
(30.7\%) used currently tobacco, $12.6 \%$ used cannabis currently, $11.1 \%$ had trouble from alcohol use, $50.0 \%$ were exposed to secondary smoke, $20.8 \%$ had multiple injuries (past year), $18.1 \%$ ever had sex, $29.1 \%$ engaged in sedentary behaviour ( $\geq 3$ hours/day), and $28.4 \%$ had five or more servings of fruit and vegetables per day. Almost one in ten of the students (7.5\%) were frequent school truant, $16.4 \%$ had low peer support, $32.8 \%$ had parents who never checked on their home work, $8.0 \%$ experienced parental emotional neglect, and $12.3 \%$ had parents who mostly or always disrespected their privacy. Almost one in six students (15.8\%) reported PD, $18.4 \%$ among females and $12.8 \%$ among males (see Table 2 ).

Table 2: Sample and psychological distress characteristics among adolescents in Bhutan, 2016

\begin{tabular}{|c|c|c|}
\hline Variable & Sample & $\begin{array}{l}\text { Psychological } \\
\text { distress }\end{array}$ \\
\hline & $\mathrm{N}(\%)$ & $\%$ \\
\hline \multicolumn{3}{|l|}{ Socio-demographics } \\
\hline All & 7576 & $1201(15.8)$ \\
\hline $\begin{array}{l}\text { Age in years } \\
14 \text { or less } \\
15-16 \\
17 \text { or more }\end{array}$ & $\begin{array}{l}2110(29.1) \\
2681(34.7) \\
2761(36.2)\end{array}$ & $\begin{array}{l}256(12.4) \\
413(15.4) \\
530(18.9)\end{array}$ \\
\hline $\begin{array}{l}\text { Gender } \\
\text { Female } \\
\text { Male }\end{array}$ & $\begin{array}{l}4105(51.9) \\
3384(48.1)\end{array}$ & $\begin{array}{l}748(18.4) \\
435(12.8) \\
\end{array}$ \\
\hline $\begin{array}{l}\text { Locality } \\
\text { Urban } \\
\text { Rural }\end{array}$ & $\begin{array}{l}3629(47.9) \\
3947(52.1)\end{array}$ & $\begin{array}{l}542(15.1) \\
659(16.7) \\
\end{array}$ \\
\hline \multicolumn{3}{|l|}{ Social distress } \\
\hline No close friends & $689(9.1)$ & $204(29.8)$ \\
\hline $\begin{array}{l}\text { Bullied in past month } \\
0 \text { days } \\
1 \text { or } 2 \text { days } \\
3-30 \text { days }\end{array}$ & $\begin{array}{l}5433(73.9) \\
1279(17.6) \\
608(8.5) \\
\end{array}$ & $\begin{array}{l}705(13.0) \\
265(20.2) \\
179(29.9) \\
\end{array}$ \\
\hline $\begin{array}{l}\text { Physically attacked in past year } \\
0 \text { times } \\
1 \text { time } \\
2 \text { or more times }\end{array}$ & $\begin{array}{l}4694(61.6) \\
1068(14.1) \\
1801(24.2)\end{array}$ & $\begin{array}{l}639(13.6) \\
189(17.3) \\
371(20.5)\end{array}$ \\
\hline $\begin{array}{l}\text { In physical fight in past year } \\
0 \text { times } \\
1 \text { time } \\
2 \text { or more times }\end{array}$ & $\begin{array}{l}4636(61.1) \\
1353(17.9) \\
1557(21.0)\end{array}$ & $\begin{array}{l}645(13.9) \\
218(16.3) \\
334(21.0)\end{array}$ \\
\hline \multicolumn{3}{|l|}{ Social-environmental factors } \\
\hline Low peer support & $1223(16.4)$ & $275(22.2)$ \\
\hline Parental emotional neglect & $604(8.0)$ & $153(24.7)$ \\
\hline Parents never check home work & $2530(32.8)$ & $501(19.7)$ \\
\hline Parents disrespect privacy & $903(12.3)$ & $169(18.3)$ \\
\hline Passive smoking in past week & $3665(50.0)$ & $674(18.2)$ \\
\hline
\end{tabular}




\begin{tabular}{|c|c|c|}
\hline $\begin{array}{l}\text { School truancy (past month) } \\
0 \text { days } \\
1-2 \text { days } \\
3 \text { or more days }\end{array}$ & $\begin{array}{l}5645(74.8) \\
1307(17.8) \\
550(7.5)\end{array}$ & $\begin{array}{l}820(14.5) \\
253(19.0) \\
119(22.1)\end{array}$ \\
\hline \multicolumn{3}{|l|}{ Health risk behaviours } \\
\hline Current tobacco use & $2226(30.7)$ & $424(18.6)$ \\
\hline Current cannabis use & $916(12.6)$ & $177(19.1)$ \\
\hline Trouble from alcohol use & $788(11.1)$ & $197(25.1)$ \\
\hline Ever sex & $1256(18.1)$ & $256(20.4)$ \\
\hline $\begin{array}{l}\text { Leisure time sedentary behaviour/day } \\
<3 \text { hours } \\
3-4 \text { hours } \\
5-8 \text { hours } \\
>8 \text { hours }\end{array}$ & $\begin{array}{l}5389(70.9) \\
1285(17.2) \\
580(7.9) \\
296(4.0)\end{array}$ & $\begin{array}{l}787(14.5) \\
220(16.8) \\
111(19.2) \\
76(26.8)\end{array}$ \\
\hline $\begin{array}{l}\text { Injury in past } 12 \text { months } \\
0 \text { times } \\
1 \text { time } \\
2 \text { or more times } \\
\end{array}$ & $\begin{array}{l}3909(56.2) \\
1561(23.0) \\
1422(20.8)\end{array}$ & $\begin{array}{l}459(11.7) \\
273(17.0) \\
347(24.6) \\
\end{array}$ \\
\hline $\begin{array}{l}\text { Fruit and vegetable intake } \\
<1 \text { serving/day } \\
1 \text { or } 2 \\
3 \text { or } 4 \\
5 \text { or more } \\
\end{array}$ & $\begin{array}{l}1199(15.8) \\
2102(27.8) \\
2111(28.0) \\
2103(28.4)\end{array}$ & $\begin{array}{l}227(19.2) \\
345(16.2) \\
284(13.7) \\
330(15.3)\end{array}$ \\
\hline
\end{tabular}

\section{Associations with psychological distress}

In the adjusted logistic regression analysis, female sex, having no close friends, older age, bullying victimization, infrequently physically attacked, parental emotional neglect, parents never check home work, passive smoking, trouble from alcohol use, ever having sex, high sedentary behaviour, and having sustained a single or multiple serious injuries (past year) were associated with PD. In addition, adequate fruit and vegetable consumption was protective against PD (see Table 3).

Table 3: Associations with psychological distress among adolescents in Bhutan

\begin{tabular}{|l|l|l|}
\hline Variable & $\begin{array}{l}\text { Unadjusted Odds Ratio } \\
(95 \% \mathrm{CI})\end{array}$ & $\begin{array}{l}\text { Adjusted Odds Ratio } \\
(95 \% \mathrm{CI})\end{array}$ \\
\hline Socio-demographics & & \\
\hline Age in years & & 1 (Reference) \\
14 or less & 1 (Refence) & $1.36(1.13,1.64)^{* *}$ \\
$15-16$ & $1.69(1.52,1.89)^{* * *}$ & $1.79(1.34,2.38)^{* * *}$ \\
17 or more & $2.64(2.20,3.15)^{* * *}$ & 1 (Reference) \\
\hline Gender & 1 (Reference) & $0.49(0.40,0.58)^{* * *}$ \\
Female & $0.61(0.55,0.68)^{* * *}$ & \\
Male & & 1 (Reference) \\
\hline Locality & 1 (Reference) & $1.07(0.85,1.34)$ \\
Urban & $1.12(0.89,1.42)$ & \\
\hline Rural & & \\
\hline Social distress & & \\
\hline
\end{tabular}




\begin{tabular}{|c|c|c|}
\hline No close friends & $2.78(2.40,3.22)^{* * *}$ & $2.52(1.92,3.31)^{* * *}$ \\
\hline $\begin{array}{l}\text { Bullied in past month } \\
0 \text { days } \\
1 \text { or } 2 \text { days } \\
3-30 \text { days }\end{array}$ & $\begin{array}{l}1 \text { (Reference) } \\
2.02(1.80,2.27)^{* * *} \\
4.45(3.86,5.12)^{* * *}\end{array}$ & $\begin{array}{l}1 \text { (Reference) } \\
1.35(1.06,1.71)^{*} \\
2.14(1.56,2.94)^{* * *}\end{array}$ \\
\hline $\begin{array}{l}\text { Physically attacked in past year } \\
0 \text { times } \\
1 \text { time } \\
2 \text { or more times }\end{array}$ & $\begin{array}{l}1 \text { (Reference) } \\
1.62(1.41,1.86)^{* * *} \\
2.08(1.85,2.33)^{* * *}\end{array}$ & $\begin{array}{l}1 \text { (Reference) } \\
1.29(1.00,1.66)^{*} \\
1.18(0.89,1.56)\end{array}$ \\
\hline $\begin{array}{l}\text { In physical fight in past year } \\
0 \text { times } \\
1 \text { time } \\
2 \text { or more times }\end{array}$ & $\begin{array}{l}1 \text { (Reference) } \\
1.19(1.05,1.34) \\
1.71(1.50,1.95)^{* * *}\end{array}$ & $\begin{array}{l}1 \text { (Reference) } \\
1.07(0.85,1.35) \\
1.20(0.93,1.56)\end{array}$ \\
\hline Social-environmental factors & & \\
\hline Low peer support & $1.54(1.41,1.69)^{* * *}$ & $1.19(0.97,1.47)$ \\
\hline Parental emotional neglect & $1.83(1.60,2.09)^{* * *}$ & $1.51(1.15,1.99)^{* *}$ \\
\hline Parents never check home work & $1.65(1.45,1.87)^{* * *}$ & $1.41(1.19,1.67)^{* * *}$ \\
\hline Parents disrespect privacy & $1.29(1.17,1.43)^{* * *}$ & $1.29(0.96,1.73)$ \\
\hline Passive smoking in past week & $1.22(1.11,1.33)^{* * *}$ & $1.19(1.02,1.40)^{*}$ \\
\hline $\begin{array}{l}\text { School truancy (past month) } \\
0 \text { days } \\
1-2 \text { days } \\
3 \text { or more days }\end{array}$ & $\begin{array}{l}1 \text { (Reference) } \\
1.43(1.31,1.57)^{* * *} \\
2.31(1.96,2.72)^{* * *}\end{array}$ & $\begin{array}{l}1 \text { (Reference) } \\
1.01(0.81,1.26) \\
1.15(0.83,1.60)\end{array}$ \\
\hline Health risk behaviours & & \\
\hline Current tobacco use & $1.76(1.55,2.00)^{* * *}$ & $1.15(0.90,1.46)$ \\
\hline Current cannabis use & $2.16(1.76,2.67)^{* * *}$ & $0.86(0.62,1.20)$ \\
\hline Trouble from alcohol use & $2.46(1.99,3.05)^{* * *}$ & $1.38(1.02,1.87)^{*}$ \\
\hline Ever sex & $1.55(1.29,1.85)^{* * *}$ & $1.30(1.07,1.57)^{* *}$ \\
\hline $\begin{array}{l}\text { Leisure time sedentary behaviour/day } \\
<3 \text { hours } \\
3-4 \text { hours } \\
5-8 \text { hours } \\
>8 \text { hours }\end{array}$ & $\begin{array}{l}1 \text { (Reference) } \\
1.39(1.25,1.56)^{* * *} \\
1.89(1.70,2.10)^{* * *} \\
2.71(2.34,3.15)^{* * *}\end{array}$ & $\begin{array}{l}1 \text { (Reference) } \\
1.10(0.95,1.27) \\
1.21(0.88,1.66) \\
1.58(1.08,2.31)^{*}\end{array}$ \\
\hline $\begin{array}{l}\text { Injury in past } 12 \text { months } \\
0 \text { times } \\
1 \text { time } \\
2 \text { or more times }\end{array}$ & $\begin{array}{l}1 \text { (Reference) } \\
1.76(1.60,1.93)^{* * *} \\
2.86(2.57,3.18)^{* * *}\end{array}$ & $\begin{array}{l}1 \text { (Reference) } \\
1.41(1.09,1.82)^{* *} \\
1.75(1.41,2.18)^{* * *}\end{array}$ \\
\hline $\begin{array}{l}\text { Fruit and vegetable intake } \\
<1 \text { serving/day } \\
1 \text { or } 2 \\
3 \text { or } 4 \\
5 \text { or more }\end{array}$ & $\begin{array}{l}1 \text { (Reference) } \\
0.70(0.60,0.81)^{* * *} \\
0.55(0.47,0.64)^{* * *} \\
0.71(0.61,0.83)^{* * *}\end{array}$ & $\begin{array}{l}1 \text { (Reference) } \\
0.91(0.71,1.17) \\
0.82(0.63,1.06) \\
0.73(0.56,0.96)^{*}\end{array}$ \\
\hline
\end{tabular}

$* * * \mathrm{P}<.001 ; * * \mathrm{P}<.01 ; * \mathrm{P}<.05 ; \mathrm{CI}=$ Confidence Interval

\section{Discussion}

This national study showed for the first time, the prevalence and correlates of PD in school adolescents in Bhutan. The prevalence of PD (15.8\%) in this study was higher than in a study among adolescents in India (10.5\%) [6], similar to Iran (17.7\% ( $\geq 3$ items of worthless, anxious, angriness, confusion, and insomnia) had PD [9], but lower than in 15 years and older 
persons in Bhutan (29.3\%) [10], in four Asian countries (Laos, Mongolia, Nepal, and Sri Lanka) (32.9\%, presence of any item: suicidal ideation, plan and suicide attempt, loneliness, sadness and anxiety) [7], among adolescents in Afghanistan (27.7\%: $\geq 2$ items of no close friends, loneliness, anxiety, suicidal ideation, and suicide attempt) [8]. PD seems to be common in Bhutan, calling for strategies and programmes to prevent and control PD within this adolescent population in Bhutan.

The study showed that being female increased the likelihood of PD, which was also found in some previous investigations [16,18]. Generally, "girls are more likely than boys to report internalising problems such as $\mathrm{PD}$, depression, and anxiety." $[4,19]$. The study showed that older age increased the likelihood of PD. Similar results were found in a study among adolescents in India [6]. Possible reasons for higher PD among older than younger adolescents include increasing demands, physical and psychosocial changes [4,20].

In line with former research findings [7,8,21], this survey showed that having social distress, such as having no close friends, bullying victimization and infrequently physically attacked increased the odds for PD. Students exposed to interpersonal violence victimization may worry about further or future victimization increasing PD. In addition, our study findings demonstrate that students who had been frequently bullied had the second highest odds for PD, which concurs with former research [22]. This finding may highlight the relevance of anti-bullying programme activities to ameliorate PD.

Several social-environmental factors (parental emotional neglect, parents never check home work, and passive smoking) were found associated with PD. These results are consistent with various previous investigations [7,14,23,24] and call for programmes improving parental support. A previous review provides evidence that "parental training and school-based interventions can reduce symptoms of common mental disorders in adolescents" [25].

In terms of health risk behaviours, trouble from alcohol use, ever having sex, high leisure-time sedentary behaviour, infrequent fruit and vegetable consumption, and having experienced single and multiple serious injuries increased the likelihood of having PD. These findings concur with previous studies [14,18,26-31]. Since this study did not assess the type of sedentary behaviour, for example, social media use, we are not able to show the potentially negative effects of social media use on PD [32]. In a systematic review among adolescents [33] (p.18) found that sedentary behaviour was associated with poor mental health and PD, which may be explained by "beneficial pathophysiological, social and general health effects of being active may be omitted when sedentary, which may have a negative impact on mental 
health." Another possible mechanism by which sedentary behaviour may increase PD is via inflammatory processes [34]. Possible reasons for the protective effect of fruit and vegetable consumption against PD may lie in the antioxidant and anti-inflammatory components of fruit and vegetables enhancing well-being [26,31]. The association between injury occurrence in the past 12 months and PD in the past 12 months may be explained by "the injury occurrence being considered a particularly impactful stressful life event, and experiences of stressful life events have been strongly associated with prospective anxiety symptom development" [35]. Based on a systematic review, "psychological and psychosocial interventions" might be effective in reducing PD among adolescents in low- and middle-income countries [36].

\section{Study limitations}

Study limitations include the self-report of the data, cross-sectional design, and the focus on school adolescents. An additional limitation was that the GSHS in Bhutan only assessed PD with two items which may not reflect a standardized scale nor a diagnostic interview.

\section{Conclusion}

Almost one in six participants reported PD in a nationally representative sample of school adolescents in Bhutan. Several risk factors, including female sex, having no close friends, older age, bullying victimization, infrequently physically attacked, parental emotional neglect, parents never check home work, passive smoking trouble from alcohol use, ever having sex, high sedentary behaviour, having sustained single or multiple serious injuries (past year) and inadequate fruit and vegetable consumption, were identified for PD, which can facilitate school health promotion.

Author Contributions: "All authors fulfill the criteria for authorship. S.P. and K.P. conceived and designed the research, performed statistical analysis, drafted the manuscript and made critical revisions of the manuscript for key intellectual content. All authors have read and agreed to the published version of the manuscript."

Funding: "This research received no external funding." 
Acknowledgments: "The data source, the World Health Organization NCD Microdata Repository (URL: https://extranet.who.int/ncdsmicrodata/index.php/catalog), is hereby acknowledged."

Conflict of Interest: "The authors declare no conflict of interest."

\section{References}

1. World Health Organization (WHO) (2019). Adolescent mental health. URL:

https://www.who.int/news-room/fact-sheets/detail/adolescent-mental-health (accessed 2 Jan 2020)

2. Polanczyk GV, Salum GA, Sugaya LS, Caye A, Rohde LA. Annual research review: A meta-analysis of the worldwide prevalence of mental disorders in children and adolescents. J Child Psychol Psychiatry. 2015;56(3):345-365. doi:10.1111/jcpp.12381

3. Kessler, R. C., Amminger, G. P., Aguilar-Gaxiola, S., Alonso, J., Lee, S., \& Üstün, T. B. (2007). Age of onset of mental disorders: A review of recent literature. Current Opinion in Psychiatry. doi:10.1109/CCECE.2006.277836

4. Marsh, I.C., Chan, S.W.Y. \& MacBeth, A. Self-compassion and Psychological Distress in Adolescents - a Meta-analysis. Mindfulness 9, 1011-1027 (2018). https://doi.org/10.1007/s12671-017-0850-7

5. American Psychological Association (APA) (2020) Dictionary of Psychology: Psychological distress. URL https://dictionary.apa.org/psychological-distress 6. Jaisoorya, T. S., Geetha, D., Beena, K. V., Beena, M., Ellangovan, K., \& Thennarasu, K. (2017). Prevalence and correlates of psychological distress in adolescent students from India. East Asian Archives of Psychiatry, 27(2), 56-62.

7. Lee, H., Lee, E. Y., Greene, B., \& Shin, Y. J. (2019). Psychological distress among adolescents in Laos, Mongolia, Nepal, and Sri Lanka. Asian Nursing Research, 13(2), 147-153. https://doi.org/10.1016/j.anr.2019.04.001.

8. Pengpid S, Peltzer, K. High psychological distress among school-going adolescents in Afghanistan: prevalence and correlates from a national survey. Vulnerable Child Youth Stud. 2020;15(1): 40-47. https://doi.org/10.1080/17450128.2019.1679937

9. Ahadi Z, Qorbani M, Kelishadi R, Ardalan G, Taslimi M, Mahmoudarabi M, Motlagh ME, Asayesh H, Shafiee G, Larijani B, Heshmat R. Regional disparities in psychiatric distress, violent behavior, and life satisfaction in Iranian adolescents: the CASPIAN-III study. J Dev Behav Pediatr. 2014;35(9):582-90. doi: 10.1097/DBP.0000000000000103. 
10. Sithey, G., Li, M., Wen, L. M., Kelly, P. J., \& Clarke, K. (2018). Socioeconomic, religious, spiritual and health factors associated with symptoms of common mental disorders: a cross-sectional secondary analysis of data from Bhutan's Gross National Happiness Study, 2015. BMJ open, 8(2), e018202. https://doi.org/10.1136/bmjopen2017-018202

11. Wangchuk, P., Hengudomsub, P., Chaimongkol, N. (2016) Relationships between Protective Factors and Mental Health of Adolescents in Mongar, Bhutan. Thai Pharmaceutical and Health Science Journal 2016;11(2):49-61.

12. Kieling, C., Baker-Henningham, H., Belfer, M., Conti, G., Ertem, I., Omigbodun, O., et al. (2011). Child and adolescent mental health worldwide: Evidence for action. Lancet, 378(9801), 1515-1525. https://doi.org/10.1016/S0140-6736(11)60827-1.

13. Khan, M., Rahman, M. M., Islam, M. R., Karim, M., Hasan, M., \& Jesmin, S. S. (2020). Suicidal behavior among school-going adolescents in Bangladesh: findings of the global school-based student health survey. Social psychiatry and psychiatric epidemiology, 10.1007/s00127-020-01867-z. Advance online publication. https://doi.org/10.1007/s00127-020-01867-z

14. Pengpid, S., Peltzer, K. (2020) Psychological distress and its associated factors among school-going adolescents in Tanzania. Psychological Studies. https://doi.org/10.1007/s12646-020-00550-2

15. World Health Organization (WHO) (2019). Global school-based student health survey (GSHS). URL: https://www.who.int/ncds/surveillance/gshs/en/ (accessed 10 September 2020)

16. Pengpid, S., \& Peltzer, K. Prevalence and associated factors of psychological distress among a national sample of in-school adolescents in Morocco. BMC Psychiatry. DOI: 10.1186/s12888-020-02888-3

17. World Health Organization (WHO) (2016) Adverse Childhood Experiences International Questionnaire (ACE-IQ) Guidance for Analysing ACE-IQ. URL: https://www.who.int/violence_injury_prevention/violence/activities/adverse_childhood _experiences/guidance_for_analysing.pdf?ua=1 (accessed 2 April 2020)

18. Pengpid, S., \& Peltzer, K. (2019). Leisure-time sedentary behavior is associated with psychological distress and substance use among school-going adolescents in five Southeast Asian countries: A cross-sectional study. International Journal of Environmental Research and Public Health, 16, 2091; doi:10.3390/ijerph16122091 
19. Angold A, Erkanli A, Silberg J, Eaves L, Costello EJ (2002) Depression scale scores in 8-17-year-olds: effects of age and gender. J Child Psychol Psychiatry 43:1052-1063

20. Byrne, D., Davenport, S., \& Mazanov, J. (2007). Profiles of adolescent stress: the development of the adolescent stress questionnaire. Journal of Adolescence, 30(3), $393-416$.

21. Landstedt, E., \& Gillander Gådin, K. (2011). Experiences of violence among adolescents: gender patterns in types, perpetrators and associated psychological distress. International journal of public health, 56(4), 419-427. https://doi.org/10.1007/s00038-011-0258-4

22. Fleming, L. C., \& Jacobsen, K. H. (2010). Bullying among middle-school students in low and middle income countries. Health Promotion International, 25(1), 73-84. doi: 10.1093/heapro/dap046.

23. Siziya, S., \& Mazaba, M. L. (2015). Prevalence and correlates for psychosocial distress among in-school adolescents in Zambia. Frontiers in Public Health, 3(180), 2015. https://doi.org/10.3389/fpubh.2015.00180. (eCollection 2015).

24. Beattie, T. S., Prakash, R., Mazzuca, A., Kelly, L., Javalkar, P., Raghavendra, T., Ramanaik, S., Collumbien, M., Moses, S., Heise, L., Isac, S., \& Watts, C. (2019). Prevalence and correlates of psychological distress among 13-14 year old adolescent girls in North Karnataka, South India: a cross-sectional study. BMC public health, 19(1), 48. https://doi.org/10.1186/s12889-018-6355-z

25. Klasen, H., \& Crombag, A. C. (2013). What works where? A systematic review of child and adolescent mental health interventions for low and middle income countries. Social Psychiatry and Psychiatric Epidemiology, 48(4), 595-611. doi: 10.1007/s00127-0120566-x.

26. Hong, S.A., Peltzer, K. (2017). Dietary behaviour, psychological well-being and mental distress among adolescents in Korea. Child Adolescent Psychiatry and Mental Health, 11, 56. doi: 10.1186/s13034-017-0194-z. eCollection 2017.

27. Jacob, L., Smith, L., Haro, J. M., Stickley, A., \& Koyanagi, A. (2020). Serious physical injury and depressive symptoms among adolescents aged 12-15 years from 21 low- and middle-income countries. Journal of affective disorders, 264, 172-180. https://doi.org/10.1016/j.jad.2019.12.026

28. Pengpid, S., \& Peltzer, K. (2019). Early substance use initiation and psychological distress among adolescents in five ASEAN countries. Psychology Research and Behavior Management, 12, 1003-1008. http://doi.org/10.2147/PRBM.S223624 
29. Smith, L., Jackson, S. E., Vancampfort, D., Jacob, L., Firth, J., Grabovac, I., McDermott, D., Yang, L., López-Sánchez, G. F., Niederkrotenthaler, T., Veronese, N., \& Koyanagi, A. (2020). Sexual behavior and suicide attempts among adolescents aged 12-15 years from 38 countries: A global perspective. Psychiatry research, 287, 112564. https://doi.org/10.1016/j.psychres.2019.112564

30. Williams, J. L., Rheingold, A. A., Knowlton, A. W., Saunders, B. E., \& Kilpatrick, D. G. (2015). Associations between motor vehicle crashes and mental health problems: data from the National Survey of Adolescents-Replication. Journal of traumatic stress, 28(1), 41-48. https://doi.org/10.1002/jts.21983

31. Liu, M. W., Chen, Q. T., Towne, S. D., Jr, Zhang, J., Yu, H. J., Tang, R., Gasevic, D., Wang, P. G., \& He, Q. Q. (2020). Fruit and vegetable intake in relation to depressive and anxiety symptoms among adolescents in 25 low- and middle-income countries. Journal of affective disorders, 261, 172-180. https://doi.org/10.1016/j.jad.2019.10.007

32. Keles B, McCrae N \& Grealish A (2020) A systematic review: the influence of social media on depression, anxiety and psychological distress in adolescents, International Journal of Adolescence and Youth, 25:1, 79-

93, DOI: $10.1080 / 02673843.2019 .1590851$

33. Hoare, E., Milton, K., Foster, C., \& Allender, S. (2016). The associations between sedentary behaviour and mental health among adolescents: a systematic review. The international journal of behavioral nutrition and physical activity, 13(1), 108. https://doi.org/10.1186/s12966-016-0432-4

34. Vancampfort, D., Van Damme, T., Stubbs, B., Smith, L., Firth, J., Hallgren, M., Mugisha, J., \& Koyanagi, A. (2019). Sedentary behavior and anxiety-induced sleep disturbance among 181,093 adolescents from 67 countries: a global perspective. Sleep medicine, 58, 19-26. https://doi.org/10.1016/j.sleep.2019.01.048

35. McLaughlin, K. A., \& Hatzenbuehler, M. L. (2009). Stressful life events, anxiety sensitivity, and internalizing symptoms in adolescents. Journal of abnormal psychology, 118(3), 659-669. https://doi.org/10.1037/a0016499

36. Uppendahl, J. R., Alozkan-Sever, C., Cuijpers, P., de Vries, R., \& Sijbrandij, M. (2020). Psychological and Psychosocial Interventions for PTSD, Depression and Anxiety Among Children and Adolescents in Low- and Middle-Income Countries: A MetaAnalysis. Frontiers in psychiatry, 10, 933. https://doi.org/10.3389/fpsyt.2019.00933 